\title{
Adapting in Digital Era of Globalized Agro- food System and Delivery of UN SDGs 1 and 2: Agriculture Extension in Small-scale Red Onion (Shallot) Horticulture Area in Highland Solok District, Indonesia
}

\author{
Helmi $^{1}$, Nala Sari Tanjung ${ }^{2}$, Lucy Natami Figna ${ }^{3}$, Virra Putri Silviana ${ }^{4}$
}

\begin{abstract}
Small-scale red onion farmers is currently in dilemmatic position with regard to their horticulture farming in highland Solok District. In one hand they are involving in a high value crop farming, but on the other they were not obtain deserved price margin of the traded red onion product. It is related to fundamental problems of limited knowledge and practices of red onion production, access to market, and public policy support. These problems entailed in relatively lower revenue and high production costs. These complex problems partly related to agriculture extension and marketing of red onion product. Solutions to these problems in digital era of globalized agro-food systems, potentially can come from a reform which integrating digital aspect into agriculture extension and marketing of the product. This research attempted to contribute to discourse of SDG 1 (no poverty) and SDG 2 (sustainable agriculture) delivery by conducting an exploratory study to develop a framework for reform of red onion agriculture extension and marketing (along value chain) of small-scale horticulture farmers.
\end{abstract}

Keywords - agriculture extension, digital adaptation, marketing of horticulture product, small-scale farming, value chain.

\section{INTRODUCTION}

Sustainable development concept is continuously implemented by UN through Sustainable Development Goals (SDGs) which are expected to tackle world problems. The issue of poverty (SDGs 1) and sustainable agriculture through food security (SDGs 2) become the most important issues that must continue to be implemented to be fulfilled until 2030. The agricultural sector is the main sector in supporting the sustainability of the implementation of these objectives. Sustainable agricultural development has three interrelated aspects: economic, social, and environment in improving the wellfare of farmers and related stakeholders, so that it is integrated with the reduction in community poverty.

\footnotetext{
${ }^{1}$ Helmi, Department of Agribusiness, Faculty of Agriculture, Andalas University, Padang 25163, email: helmi @agr.unand.ac.id

${ }^{2}$ Depart Nala Sari Tanjung, ment of Agribusiness, Faculty of Agriculture, Andalas University, Padang 25163, email: nalatanjung@ gmail.com

3 Lucy Natami Figna, Department of Agribusiness, Faculty of Agriculture, Andalas University, Padang 25163, email: lucynatami@gmail.com

4 Virra Putri Silviana, Department of Agribusiness, Faculty of Agriculture, Andalas University, Padang 25163
}

Various efforts made to achieve these objectives require an integrated approach because the three aspects are interconnected.

There are complex problems in sustainable agricultural development activities along the value chain (from production to distribution) faced by farmers in Indonesia. Mostly, farmers in Indonesia are small farmers, characterized by narrow land area, dominated by the use of labor in the family, lack of access and lack of resources so that the scale of business that is not economic and low income has low human resources and other limited resources.

One of the commodities made a major contribution to sustainable agriculture development is the red onion (shallot) horticulture farming. In Indonesia, the most contributed area to productivity of shallots in West Sumatra is Lembah Gumanti District, Solok Regency. Rusli and Burhanuddin (2014)[1] stated that Solok Regency is one area that has the potential to become one of the centers of onion production because it has the largest production and planting area of shallots in West Sumatra. Lembah Gumanti District produces 55,077 tons of shallots with a productivity of 11.83 tons / ha and a harvest area of 4,655 ha. Shallots are the most widely grown commodity in Lembah Gumanti District compared to other commodities.

The government currently has built collaborations with multistakeholders to advance Solok Regency's shallot agriculture, such as establishing a cooperative agreement on the development of a shallot cluster. But in fact, onion farmers are still often faced with various problems, such as unstable weather conditions, high humidity, causing increased pests and plant diseases, lack of innovation, limited market access, difficulties in marketing, and low use of digital media (literacy) digital) by shallot growers.

Agricultural extension has an important role in ensuring the sustainability of shalot farming activities. Agricultural extension activities for shalot farmers in Lembah Gumanti District are generally carried out by three parties: Agricultural Extentiton Center (AEC) agents, self-suport extention agents, and private extension agents. However, generally the extention activities by the three types of agents are still focused on the production and post-harvest subsystems. Meanwhile, marketing-related activities tend to be weak. In addition, the role of the three types of instructors is still weak, both cooperation and coordination 
between types of extension agents (self-suport, private, and AEC agent). To overcome these problems, collaboration between the parties involved is an important element in determining the success and sustainability of extension activities. The success of extension activities is largely determined by the role played and the collaboration that occurs between the multi-parties involved directly in the extension activities.

In today's digital era, information and communication technology really needs to be developed to support the welfare of farmers. Based on the results of a World Bank study, development of information technology will affect the development of agricultural technology because it can increase crop productivity, so that information technology (World Bank, 2011)[2]. Basically, the required information is available and can be accessed through various media such as television, radio, newspapers, magazines, and websites. But among these media, internetbased digital media such as websites are believed to be the most reliable media and able to provide information according to farmers' needs. Internet-based digital media or online media are able to provide information in various forms, such as text, audio, and video. In addition, digital media is also able to provide various applications that can help improve the capacity of farmers in information literacy. Therefore, increasing digital literacy in supporting education along the shallot farming value chain is needed to achieve the goals of SDGs 1 (no poverty) and 2 (sustainable agriculture).

This study seeks to understand the extension activities along the value chain, digital literacy, and the role of AEC in facilitating the development of small-scale shallot farming in its working area.Furthermore, this research aims to develop a framework for reform of red onion agriculture extension and marketing (along value chain) of small-scale shallot farmers.

\section{METHOD}

This research uses exploratory study. Exploratory study is a type of research aimed to collect preliminary information would help efforts to determine the problem and formulate a hypothesis (Kotler, 2010)[3]. This research was conducted for three months, SeptemberNovember 2019, in Lembah Gumanti District, Solok Regency, West Sumatra. The population in this study were onion farmers in Lembah Gumanti District, Solok Regency. Sampling is done by multistage cluster sampling, which is a sampling technique in stages. First, sampling is done purposively (intentionally), which is farmers'vgroup who are still active shallot farmers in the District of Lembah Gumanti. Furthermore, sampling is taken by census, which is all members of farmers' group who are still active in each of the selected groups. Based on this determination, 37 respondents were obtained from six active onion farmers' group in Lembah Gumanti Subdistrict: Alhamdulillah Farmers' Group, Harapan Baru Farmers' Group, Sunrise Farmers' Group, Sungai Nanam Farmers' Group, Sumber Rezeki Farmers' Group, and Usaha Baru Farmers' Group. Furthermore, this study took key informants consisting of 2 AEC agents, 2 self-support extention agents, and 3 private extention agents. Data obtained from the scoping activity of the study were analyzed qualitatively, while the data obtained from the survey were processed descriptively.

\section{RESUlTS AND DiscUSSION}

\section{A. Activities along the Shallot Farm Value Chain}

Shallots are a very important commodity in daily life. Shallots have fluctuating prices caused by erratic productivity affected by the season, causing farmers to experience a decline in production. Shallot is an agricultural product that requires intensive handling and shallot is a perishable commodity. The following section presents how farmers carry out farming activities along the value chain and the problems.

\section{1) Production}

Cultivation techniques of shallot farmers in Lembah Gumanti is similiar to cultivation techniques listed in the guidelines according to the Ministry of Agriculture. Problems in the production (cultivation) sector generally are:

a) Farmers' inability to measure the right soil $\mathrm{pH}$

b) Lack of knowledge of farmers in providing fertilizer in accordance the dose. Thus, farmers mix various types of fertilizers with uncertain amounts, such as from manure, organic fertilizer, to inorganic fertilizers (ig: ZA, SP36, NPK, Horse NPK, SP6, SS, etc.). This causes an increase in production costs.

c) Lack of knowledge of farmers in providing chemical poisons such as pesticides, herbicides, and fungicides (generally farmers mix several types of chemical poisons in one time). This causes an increase in production costs.

d) Difficulties in accessing water for irrigation. Hence, farmers are vulnerable to the risk of crop failure, especially during the dry season.

2) Harvest and Post-Harvest

Harvesting is done manually, by pulling the onion bulbs by hand. After that, drying activity is carried out for 10 days to 14 days. Post-harvest activities are carried out by sorting the dried onions. Sorting is divided into 4 classes with different prices, named "jumbo, super jumbo, super, and ampera". The problem with harvesting and postharvesting is that onions will dry longer in rainy season

\section{3) Distribution / Market}

Farmers are generally sell shallots to collectors because they are more efficient and save farmers time. However, there are some farmers who also sell onions to consumers directly because of higher selling prices. The problem with the marketing of shallots is that prices are very fluctuative and often very low, and farmers have no the power to set prices. Another problem is the accumulation of onions, especially there are another shallots from outside or overseas, and collectors is not directly paid the price.

The development of shallot agribusiness in the future is directed to: (a) the development of shallots varieties equivalent to the quality of imports as one of the substitution efforts (reducing dependence on imported supplies), (b) the development of the shallot seed industry in the context of maintaining a sustainable supply of quality seeds, (c) expansion of the shallot planting area as 
an effort to anticipate increased consumption, and (d) the development of diversification of shallot products in an effort to increase added value (Bank Indonesia, 2013)[4].

Based of the description, the problem of shallot farming occured along the value chain is in fact very contrary to the goal of SDGs 1 (no poverty) because the cost increases while the prices obtained by farmers are low, and SDGs 2 (sustainable agriculture) because the shallot farming activities by farmers use very much anorganic fertilizer and excess use excessive use of pesticides, herbicides, and fungicides.

\section{B. Digital Literacy in the Implementation of Shallots Extention}

Lembah Gumanti District in Solok Regency is one of the centers of agricultural production in the horticulture sector, especially shallot. As stated by Rusli and Burhanuddin (2014)[1], Solok Regency is the area with the largest production and planting area of shallots in West Sumatra, the potential for shallot development in Lembah Gumanti District is very large. Therefore, shallot farmers in Gumanti District need to increase their capacity. Increasing the capacity of farmers is closely related to their accessibility of information.

Observation shows that accessibility of information of shallot farmers in Lembah Gumanti is still low. This is caused by the lack of ownership and using of smartphones by farmers. Mansyur (2016)[5] and Imran (2010)[6] mention that Indonesian farmers lived in rural areas are still not familiar with digital media, so that they have low levels of digital literacy. Mansyur (2016)[5] explains that the digital divide which is the majority occurring in rural areas certainly results in low levels of digital literacy by the community. The low level of digital literacy is usually influenced by the social environment, education, and the availability of digital media facilities in some parts of Indonesia, including in Lembah Gumanti.

Shallot farmers in Lembah Gumanti generally do not have smartphones because they do not have the funds to buy a smartphone. In addition, most onion farmers also do not understand how to use smartphones, so they only rely on children or wives. Based on research data, this is partly due to the age of farmers who are old and no longer have the desire to use new technology. This is as mentioned by Riana et al. (2015)[7] and Sadono et al. (2014)[8] that the age of an old farmer generally reduces a person's productive ability because the older a person is, the more difficult it will be to receive information and adopt technology, including digital media. Furthermore, the education level of farmers who are generally low also makes the ability of farmers to adopt new technology slower. High or low level of education caused a person's ability to receive information. Someone who is better educated and has more technical knowledge will be more receptive to better innovation and technology. On the contrary, as mentioned by Sadono et al. (2014)[8] the low level of education is the cause of the low ability of farmers to manage their farms because of their low ability to receive technology and information, including the use of digital media as happened to shallot farmers in Lembah Gumanti District.

The use of smartphones by farmers should be directed at increasing access to information on the needs of onion farming, both in terms of cultivation, harvest, post-harvest, marketing, to price. The use of smartphones by can also be directed to access more diverse capital information, because until now, farmers still have difficulty in accessing business capital sources with soft credit. As mentioned by Ratnasari (2008)[9] and Zahedi and Zahedi (2012)[10], rural communities need economic, educational, government, health and other information, so that the use of digital media in agriculture in particular can increase the acceleration of information flow from sources source of information to farmers. Until the time the research was conducted, generally farmers who already had a smartphone always routinely accessed various matters related to shallots, both in terms of cultivation, prices, to the market regarding onions, both via google and youtube channels. However, this cannot be done in a long time, because the general use of smartphones by farmers is only around one to two hours a day. This is not only due to limited credit or internet data packages, but also because of the farmers' busyness in the fields from morning to evening. Meanwhile, at night the farmers are filled gathering with family or friends.

\section{Extention by three extension agents (AEC, self- support, and private) along the Value Chain}

In this study, the counselors used as respondents consisted of 3 categories: AEC agents, self-support extention agents, and private extension agentss. AEC agents are government extension officers worked in the Solok AEC and have an Agricultural Extension Working Area (AAWA) in the shallot production center. The following is an overview of the activities of the three extension groups:

\section{1) Production}

The extension method by AEC agent uses lectures, field schools, and demonstration plots method. The method of private extension agent is generally by lecture. Selfsupport extention agent method with direct practice. The problems faced by extension agents are limited funds for AEC agents, the clash of concepts between private extension agents and AEC agents, and the difficulty of gathering farmers.

\section{2) Harvest and Post Harvest}

There is no extension activity in the harvest and postharvest, because it is not included in their duties. However, self-support agents have conducted extention and training to farmers related to processing shallots into packaged fried onions.

\section{3) Distribution / Market}

AEC agents and private extension agents do not provide counseling on the distribution / market aspects. However, self-help counselors have done it. All processed products of farmers fried onions are accommodated, then separated based on a standard grade.

D. Alternative Model of Integrated and Synergistic Marketing and Counseling Support based on Agricultural Extention Center (AEC) for Small Scale Shallots Farmers

Support for small scale shallot farmers / farming is needed in at least three ways: reducing component production costs, increasing revenue from marketing, and overcoming the problem of irrigation water shortages in the dry season. This reduction in production costs is by 
implementing Good Agricultural Practices (GAP) through extention along the shallot value chain. The largest component of production costs at the time of the study was the cost of using chemicals for pest control and plant diseases. In terms of increasing revenue from marketing, this is related to price fluctuations and the marketing chain so that it requires alternative marketing using digital approaches. Furthermore, things that affect the success of farming are drought in the dry season and availability of irrigation water.

Based on the research results, it can be identified important components to support small scale onion farmers in running their farming. The component consists of: (1) providing collaborative outreach services among three extension categories across the value chain; (2) supply and demand data management systems that are open for access by all actors related to shallot farming (farmers, extension agents, traders, and government); (3) digital (IT) platform to support the implementation of education along the value chain; and (4) support of government programs for shallot farming successful (such as irrigation water supply during the dry season, strengthening of farmer groups, drying support infrastructure, and IT infrastructure).

E. Collaborative extention along the value chain. Provision of extension services so far has been carried out by three categories of extension agents (AEC, private and self-support). The AEC extension agents have not had practical experience qualified in managing shallot farming. Therefore, the extention conducted is more about the normative substance of good agricultural practices (GAP). The shortage of government extension agents can be complemented by self-support extension agents (experienced farmers) came from farmer groups. Meanwhile, private extension agents focus more on certain parts of the value chain related to the business of the company they worked. Therefore, the three categories of extension agents can collaborate to provide extention support along the value chain so that farmers' production (supply of shallots to the market) and prices more stable. Collaboration between extension and farmer categories is carried out openly through a digital platform where both farmers and extension workers can get accurate information to make decisions along the value chain that benefits them.

F. Supply and demand data management system. Management of supply and demand data can be done by AEC. AEC has data on farmer groups, area, and planting schedule so that it can be estimated how much supply will be available at a certain time period. The supply available at this particular time can be used as a basis for supply supply to traders (both within and between regions). Conversely, traders can also inform the needs (demand) of shallots at a certain time to be sold to the market. Private extension agents can also play a role in opening market access for farmers' products. The form can be by promoting or becoming an intermediate buyer and then distributed to the market. This information disclosure about supply and demand can be used as a basis for production plans to meet market demand. This production plan will provide an overview of the needs of production facilities and agricultural equipment / machinery, which are useful for private extension workers to market their products that are relevant to farmers.

\section{G. Digital platform}

Digital platform for extension along the value chain (integrating production and marketing and synergizing extension agents). Digital platforms are needed both for production extension activities and to facilitate marketing communications. AEC as extension admininstrator in its working area has data on farmers, farmers' group, and farming (planting area, planting / harvesting schedule). With this data, AEC will be able to make an estimate of the supply of shallots to the market and a price offer. Large traders can also post the volume of onion they need at a certain time. Such information can be accessed by farmers to plan their production. For this production process, extension agents will support farmers with the necessary knowledge and technology. AEC agents on GAP, private extension agents with practical guidance on farming which are needed by farmers. Private extensionists will offer production input and core products needed to support the production process. The government through the relevant agencies can also inform their programs that are useful to support shallot farming. Financial institutions (banks and cooperatives) can also offer financing schemes that can be accessed by farmers to finance their farming.

\section{H. Government program support.}

The government through agencies / agencies related to the development of shallot horticulture needs to provide support in terms of required infrastructure such as irrigation water supply infrastructure for onion plants, drying infrastructure, and infrastructure and digital operator system personnel so that the digital platform pillar can function. In addition, government programs are also needed to strengthen the capacity of farmers and farmer institutions within a collaborative outreach framework along the value chain and marketing facilitation.

An alternative model of support for small-scale shallot farmers in the horticultural area can be illustrated as in Figure 1, Figure 2, and Figure 3. The figure provides an overview of related parties and interactions between them so that the position of small farmers in the shallot horticultural area is better.

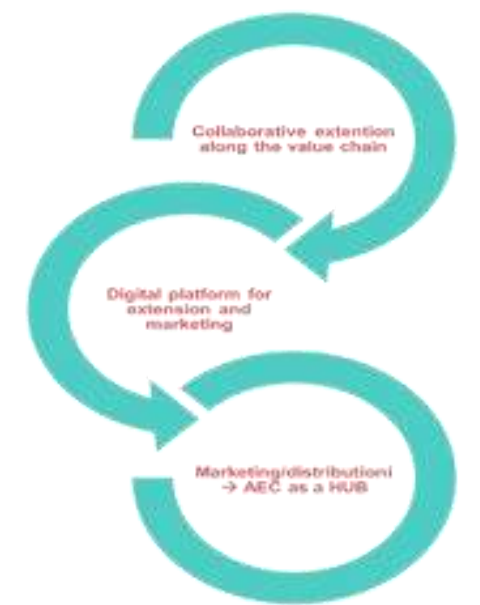

Figure 1. Alternative models of integrated extention and marketing 
There are three alternative components of an integrated extension and marketing model.

1) Collaborative extention along the value chain;

2) Digital platform for extension and marketing;

3) AEC as a hub and carry out marketing and distribution facilitation functions.

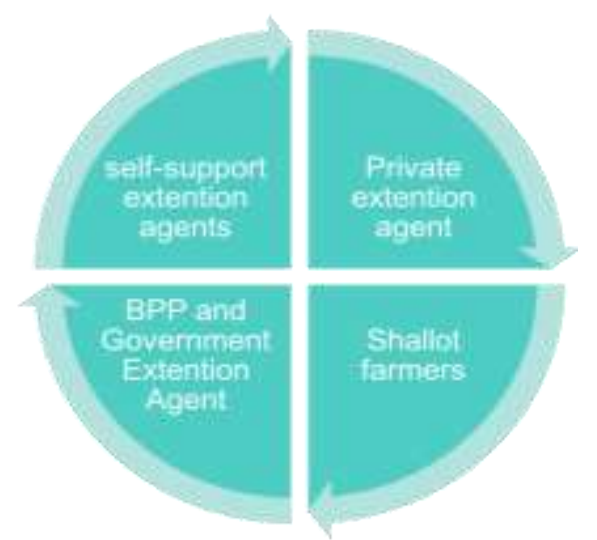

Figure 2. Collaborative Extension Along the Value Chain

The diagram is a form of collaborative extension along the value chain that will be carried out by three categories of extension agents: government, private, and self-support. This collaboration is aimed to empower farmers to manage their farms so they can take appropriate decisions regarding their farms.

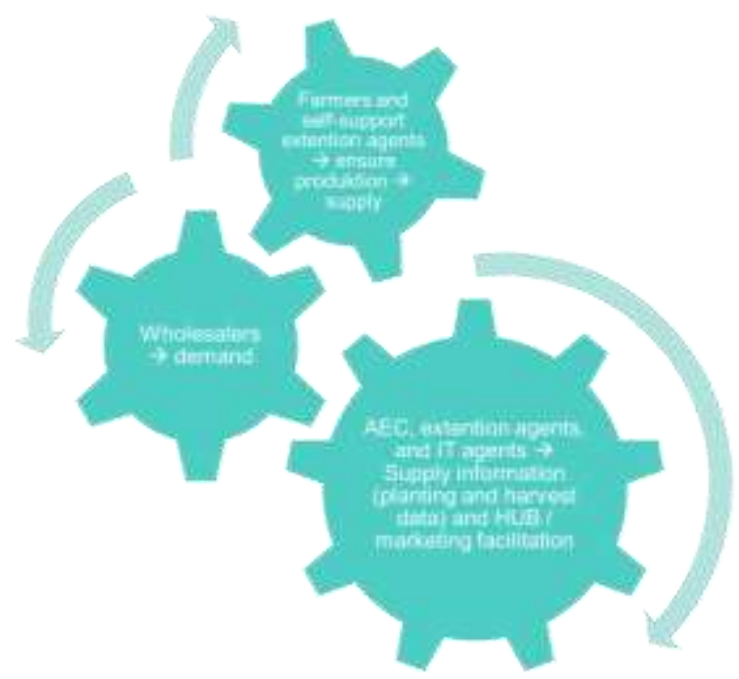

Figure 3. Multistakeholder Strategy to Support Small Scale Shallots Farmers

This multi-party synergy drives and benefits each other. All of this is managed with the support of a digital platform coordinated by AEC. AEC becomes a driving force to support small-scale farmers in AEC working area.

The model offered can help farmers reduce costs (interactive extention through digital media), especially for fertilizer costs and excessive use of pesticides (which also have an impact on reducing the use of chemicals in agricultural activities), and can increase farmers' incomes by cutting the marketing chain from collectors by using an application on smartphone that already provides an evident and guaranted price and market. Thus, this model contributes significantly in supporting the objectives of UN SDSs 1 (no poverty) and SDSs 2 (sustainable agriculture).

\section{CONCLUSION}

1. This research has succeeded in constructing alternative models of small scale integrated shallot agriculture (between production and marketing) and the synergy between the parties concerned in shallot farming in the Gumanti Valley horticultural center area.

2. The alternative model of small scale shallot farming development support consists of three main components: (1) Collaborative education along the value chain; (2) Digital platforms for extension and marketing; and (3) AEC as a HUB and performs marketing and distribution facilitation functions.

3. This support model for shallot farming development can be an alternative in a situation there is no horticultural center management unit can carried out the integration and synergy functions in the area.

\section{REFERENCES}

[1] I. R. \& B. Burhanuddin, "Potensi pengembangan bawang merah di Sumatera Barat," in Prosiding Seminar Nasional Hari Pangan Sedunia Ke-33 Optimalisasi Sumberdaya Lokal Melalui Diversifikasi Pangan Menuju Kemandirian Pangan dan Perbaikan Gizi Masyarakat Menyongsong Masyarakat Ekonomi ASEAN 2015, 2014, pp. 681-688.

[2] W. Bank, "ICT IN AGRICULTURE Connecting Smallholders to Knowledge, Networks, and Institutions," Washington, 2011.

[3] P. Kotler, Manajemen Pemasaran, Edisi tiga. Jakarta: Erlangga, 2010.

[4] Bank Indonesia, Pola Pembiayaan Usaha Kecil Menengah, Usaha Budidaya Bawang Merah. Jakarta: Departemen Pengembangan Akses Keuangan dan UMKM, 2013.

[5] F. Mansyur, "Model Pengembangan Literasi TIK Masyarakat Tani dan Nelayan," J. Pekommas, vol. 1, no. 1, pp. 101 - 110, 2016.

[6] H. A. Imran, "Literasi Teknologi Informasi dan Komunikas Masyarakat Pedesaan,” J. Stud. Komun. Dan Media, p. 19, 2010.

[7] A. S. Riana, N. Purnaningsih, "Peranan Penyuluh Swadaya dalam Mendukung Intensifikasi Kakao di Kabupaten Sigi Provinsi Sulawesi Tengah," J. Penyul., vol. 11, no. 2, pp. 201-211, 2015.

[8] S. A. D. Sadono, Sumardjo, D.S. Gani, "Farmer Empowerment in The Management of Rice Farming in Two Districts in West Java," J. Rural Indones., vol. 2, no. 1, pp. 105-126, 2014.

[9] A. Ratnasari, "Teknologi Informasi Untuk Masyarakat Pedesaan," Kaunia, vol. IV, no. 1, 2008.

[10] S.R. Zahedi \& S. M. Zahedi, "Role of Information and Communication Technologies in Modern Agriculture," Int. J. Agric. Crop Sci., 2012. 